\title{
A Study on the Socio-Personal Profile of the Farmers Practicing Integrated Fish Farming of Manipur, India
}

\author{
J.W. Haobijam ${ }^{1 *}$, Guneshori Maisnam ${ }^{2}$, Chongtham Tania ${ }^{3}$ and Souvik Chosh ${ }^{1}$ \\ ${ }^{1}$ Department of Agricultural Extension Education, P.S.B, Visva-Bharati, \\ Sriniketan (West Bengal), India \\ ${ }^{2}$ Lovely Professional University, Punjab, India \\ ${ }^{3}$ ICAR RC NEHR Manipur Centre, India \\ *Corresponding author
}

\begin{abstract}
A B S T R A C T
\end{abstract}
Keywords

Socio-personal,

Integrated-fish-

farming, Personal

interview,

Parameters,

Random sampling

Article Info

Accepted:

17 June 2019

Available Online:

10 July 2019
The present study was conducted with an objective to analyses the socio-personal profile of farmers practicing integrated-fish-farming of Manipur. This study was conducted on 300 farmers in 15 villages viz. Takcham, Tentha, Athokpam, Lameidong, Wabagai, Hiyanglam, Khabi Bomdiar, Wangoi, Uchiwa, Leimapokpam, Irengbam, Maibam, Naharup, Heyanglam, and Top. These 15 villages were selected from 5 districts viz. Thoubal, Kakching, Imphal West, Bishnupur and Imphal East district, respectively. It was aimed to analyses the Socio-personal profile of the farmers practicing the integrated-fishfarming. The study was undertaken from March 2017 to October 2018 and the data pertain of the year 2017 and 2018. In the present study, data was generated through a sample survey of farmers by personal interview method using pretested well-structured interview schedule. Random sampling was adopted for the selection of the respondents. From the study it is obtain that the farmer engages in integrated fish farming farmers have the following parameters with majority of age group show 36-60 year $(53.33 \%)$, married (96.67\%), OBC (66.67\%), High School (27.67\%), Joint family type (71.33), Family size above 5 (73.33), IFF as sole profession(48\%), member of an organization $(47.67 \%)$. The study concluded that understanding of socio-personal characteristics of the farmer practicing integrated fish farming can hold the extension agents to formulate various training design to target the specific level of farmers.

\section{Introduction}

Integrated fish farming may be known as the connection or sequential involvement of two or more human activity system, of which at least one is aquaculture. Furthermore, the linkages between aquaculture and human activities involve not only agriculture (i.e. crops, livestock, irrigation dams canals) but also include roles in sanitation (night soil, septage or other forms of human excreta reuse, sewage treatment), nutrient recovery 
(hydroponic-fish, breweries) and energy recovery (culture in heated effluents of power plants, dairies, etc.) (Prein, 2002). Integrated farming system (IFS) must be include in the Sustainable development agriculture as it will efficient soil, water crop and pest management practices, which are environmentally friendly and cost effective (Walia, 2013). Aquaculture is enriched through integration of formerly existing cultivation of crops cum horticultural, and /or agronomical or domesticated animals such as piggery, poultry, rabbitery or even wild domesticated animals such as guinea fowls, and cane rats (Olukunle, 2014). In contrast, theoreticians used to differentiate Integrated Fish Farming system from mixed farming, in which production sub-systems of a farm are not mutually supportive and do not depend on each other (Csavas, 1992). The principle of integrated fish farming involves farming of fish along with livestock and agricultural crops. This type of farming offers great efficiency in resource utilization, as waste or by-product from one system is effectively recycled. It also enables effective utilization of available farming space for maximizing production.

In any part of the country, the type and level of integration depends on the prevalent environmental conditions, social norms, cultural values and religious factors (Ayinla, 2003). Integrated fish farming combines livestock production with fish farming. Animal manure is shed directly into a fish pond as fertilizer and supports the growth of photosynthetic organisms. The livestock, mainly chickens and pigs, is often fed feed containing growth promoters (Andreas et al., 2002).

\section{Objective of study}

To explore the different socio-personal characters of the Integrated Fish Farmers of Manipur.

\section{Materials and Methods}

The study was conducted in five districts of Manipur, Thoubal, Kakching, Imphal West, Bishnupur and Imphal East. One block each from this five districts were selected purposively. Again three villages were selected for the study from each block. The 15 village viz. Tekcham, Tentha, Athokpam, Langmeidong, Wabagai, Hiyanglam, Khabi Bomdiar, Wangoi, Uchiwa, Leimapokpam, Irengbam, Maibam, Naharup, Heingang and Top dusara, with 300 farmer were study. While studying the 300 farmers, simple random sampling procedure were adopted for the study. District, block and villages for the study were selected purposively. It may be termed as multistage random sampling procedure.

Socio-personal profile of the farmers was studied by measuring different components of their socio-personal status. For this purpose the socio-personal scale has eight items viz. age, marital status, caste, education, family type, family size, occupation and socio participation which were develop according to the need of the study. The data collected were tabulated and statistical tools like frequency and percentage were used for logical conclusion of the study.

\section{Results and Discussion}

The socio-personal status of the Integrated fish farming farmers were identified in terms of age, marital status, caste, education of the respondent, family type, family size and occupation. The date of the combine sociopersonal are presented and discussed below with separate tables with frequency and percentage.

Analysis of the data from the table 1 on age indicates that more than half $(53.33 \%)$ of the integrated fish farming farmers belong to middle age group between 36 to 50 years in 
first category. (29.67\%) had 51 to 65 years of age were in second category, $(11.67 \%)$ in up to 35 years of age in third category and $(5.33 \%)$ in the 66 and above years of age in fourth.

Analysis of the data from the table 2 on marital status indicates that majority of the integrated fish farming farmers $(96.67 \%)$ were married category and $(3.33 \%)$ of the farmers were unmarried category.

Analysis of the data from table 3 on caste indicates that majority of the integrated fish farming farmers $(66.67 \%)$ of the respondents were in $\mathrm{OBC}$ category and $(33.33 \%)$ were in general category.

Table.1 Distribution of the respondents on the bases of age: $(\mathrm{N}=300)$

\begin{tabular}{|l|l|c|c|}
\hline Items & Category & Frequency & Percentage \\
\hline \multirow{2}{*}{ Age } & up to 35 year & 35 & 11.67 \\
\cline { 2 - 4 } & 36-50 year & 160 & 53.33 \\
\cline { 2 - 4 } & 51-65 year & 89 & 29.67 \\
\cline { 2 - 4 } & 66 and above year & 16 & 5.33 \\
\hline
\end{tabular}

Table.2 Distribution of the respondent based on marital status: $N=300$

\begin{tabular}{|l|l|c|c|}
\hline Items & Category & Frequency & Percentage \\
\hline Marital & Married & 290 & 96.67 \\
\cline { 2 - 4 } Status & Unmarried & 10 & 3.33 \\
\cline { 2 - 4 } & Widow & 0 & 0 \\
\hline
\end{tabular}

Table.3 Distribution of the respondent based on caste: $N=300$

\begin{tabular}{|l|l|c|c|}
\hline Items & Category & Frequency & Percentage \\
\hline Caste & General & 100 & 33.33 \\
\cline { 2 - 4 } & OBC & 200 & 66.67 \\
\cline { 2 - 4 } & Schedule Caste (SC) & 0 & 0 \\
\cline { 2 - 4 } & Schedule Tribe (ST) & 0 & 0 \\
\hline
\end{tabular}

Table.4 Distribution of the respondent on the basis of education of the respondent: $N=300$

\begin{tabular}{|l|l|c|c|}
\hline Items & Category & Frequency & Percentage \\
\hline Education & Illiterate & 35 & 11.67 \\
\cline { 2 - 4 } & Can read only & 1 & 0.33 \\
\cline { 2 - 4 } & Can read and write & 2 & 0.67 \\
\cline { 2 - 4 } & Primary & 30 & 10 \\
\cline { 2 - 4 } & Middle school & 57 & 19 \\
\cline { 2 - 4 } & High school & 83 & 27.67 \\
\cline { 2 - 4 } & Higher secondary & 64 & 21.33 \\
\cline { 2 - 4 } & Graduate & 28 & 9.33 \\
\cline { 2 - 4 } & Post Graduate & 0 & 0 \\
\cline { 2 - 4 } & Others & 0 & 0 \\
\hline
\end{tabular}


Table.5 Distribution of the respondent on the basis of family type: $\mathrm{N}=300$

\begin{tabular}{|l|l|c|c|}
\hline Items & Category & Frequency & Percentage \\
\hline $\begin{array}{l}\text { Family } \\
\text { Type }\end{array}$ & Nuclear & 86 & 28.67 \\
\cline { 2 - 4 } & Joint & 214 & 71.33 \\
\hline
\end{tabular}

Table.6 Distribution of the respondent on the basis of family size: N=300

\begin{tabular}{|l|l|c|c|}
\hline Items & Category & Frequency & Percentage \\
\hline Family & Less than 5 & 80 & 26.67 \\
\hline Size & Above 5 & 220 & 73.33 \\
\hline
\end{tabular}

Table.7 Distribution of the respondent on the basis of occupation: N=300

\begin{tabular}{|l|l|c|c|}
\hline Items & Category & Frequency & Percentage \\
\hline \multirow{3}{*}{ Occupation } & IFF as a sole profession & 144 & 48 \\
\cline { 2 - 4 } & IFF and caste profession & 18 & 6 \\
\cline { 2 - 4 } & IFF and agriculture labour & 54 & 18 \\
\cline { 2 - 4 } & IFF and Business & 70 & 23.33 \\
\cline { 2 - 4 } & IFF and Service & 14 & 4.67 \\
\hline
\end{tabular}

Table.8 Distribution of the respondent on the basis of socio participation: N=300

\begin{tabular}{|c|c|c|c|}
\hline & Category & Frequency & Percentage \\
\hline \multirow{6}{*}{$\begin{array}{l}\text { Social } \\
\text { Participation }\end{array}$} & No Member & 81 & 27 \\
\hline & Member of an organization & 143 & 47.67 \\
\hline & $\begin{array}{l}\text { Member of more than one } \\
\text { organization }\end{array}$ & 46 & 15.33 \\
\hline & Office bearer of one organization & 14 & 4.67 \\
\hline & $\begin{array}{l}\text { Office bearer of more than one } \\
\text { organization }\end{array}$ & 13 & 4.33 \\
\hline & Distinctive type & 3 & 1 \\
\hline
\end{tabular}

Analysis of the table 4 on education of the respondent indicates that majority of the integrated fish farming farmers $(27.67 \%)$ were in high school category, (21.33\%) higher secondary was in second category, $(19 \%)$ middle school in the third category, $(11.67 \%)$ illiterate in the fourth category, $(10 \%)$ primary in the fifth category, $(9.33 \%)$ graduate in the sixth category. $(0.67 \%)$ can read and write in the seventh category and $(0.33 \%)$ can read only in the eight category.
Analysis of the table 5 on family type of the respondent indicated that majority of the integrated fish farming farmers $(71.33 \%)$ were joint family type and $(28.67 \%)$ of farmers were in nuclear family type.

Analysis of the table 6 of family size indicates that majority of the integrated fish farming farmers $(73.33 \%)$ were above 5 member's category and $(26.67 \%)$ of the farmers were less than 5 members. 
Analysis of the table 7 on occupation indicates that majority of integrated fish farming farmers $(48 \%)$ are the integrated fish farming (IFF) as a sole profession, (23.33\%) IFF and business as in the second category, (18\%) IFF and agriculture labour in the third category, (6\%) IFF and caste profession in the fourth category and $(4.67 \%)$ in the fifth category.

Analysis of the table 8 on socio participation indicates that majority of integrated fish farming farmers $(47.67 \%)$ are member of an organization, (27\%) no member of an organization in the second category, $(15.33 \%)$ member of more than one organization in the third category, $(4.67 \%)$ office bearer of one organization in the fourth category, $(4.33 \%)$ office bearer of more than one organization in the fifth category and (1\%) distinctive type in the sixth category.

In conclusion, the demand for the fish will be increasing day by day along with the other agricultural items as the population is continuously increasing but the cultivable area is decreasing continuously. Integrated fish cultivation has a very large scope with sustainable methods and earning more with more production to meet the various demands in the coming future. But there is still gap between the farmers and the concern authorities of agriculture department. By knowing the various personal characteristics of the farmers, the concern authority can design particularly with the specific level of farmers to make them understand and narrow the various training methods by the research persons.

\section{Acknowledgments}

I would like to thank my guide Prof. Souvik Ghosh, Department of Agricultural Extension, Institute of Agriculture, Visva-Bharati University, Sriniketan and co-authors for their kind support and valuable guidance, to construct and criticisms during the course of investigation and for the preparation of the manuscript.

\section{References}

1. Andreas Petersen, Jens Strodl Andersen, Tawatchai Kaewmak, Temdoung Somsiri and Anders Dalsgaard (2002). Impact of Integrated Fish Farming on Antimicrobial Resistance in a Pond Environment. Applied Environment Microbiology. 68(12): 6036-6042.

2. Ayinla, O. A. (2003). Integrated fish farming: A veritable tool for poverty alleviation/ Hunger eradication in the Niger Delta region. Conference Proceedings of Fisheries Society of Nigeria, Owerri, Nigeria. Pp. 40-49.

3. Csavas, I. (1992). Regional review on livestock-fish production systems in Asia. Proceedings of the FAO/IPT Workshop on integrated livestock-fish production system. Pp. 16-20.

4. Prein, M. (2002). Integration of aquaculture into crop-animal systems in Asia. Agricultural Systems, 71: 127-146.

\section{How to cite this article:}

Haobijam, J.W., Guneshori Maisnam, Chongtham Tania and Souvik Chosh. 2019. A Study on the Socio-Personal Profile of the Farmers Practicing Integrated Fish Farming of Manipur, India. Int.J.Curr.Microbiol.App.Sci. 8(07): 2306-2310.

doi: https://doi.org/10.20546/ijcmas.2019.807.281 